MT-DP - 2015/31

\title{
Political Incentives and State Subsidy Allocation: Evidence from Hungarian Municipalities
}

\author{
BALÁZS MURAKÖZY - ÁLMOS TELEGDY
}




\title{
Discussion papers
}

MT-DP - 2015/31

Institute of Economics, Centre for Economic and Regional Studies, Hungarian Academy of Sciences

KTI/IE Discussion Papers are circulated to promote discussion and provoque comments. Any references to discussion papers should clearly state that the paper is preliminary. Materials published in this series may subject to further publication.

Political Incentives and State Subsidy Allocation:

Evidence from Hungarian Municipalities

Authors:

\author{
Balázs Muraközy \\ senior research fellow \\ Institute of Economics - Centre for Economic and Regional Studies \\ Hungarian Academy of Sciences \\ e-mail: murakozy.balazs@krtk.mta.hu \\ Álmos Telegdy \\ senior researcher \\ National Bank of Hungary \\ visiting recurrent associate professor \\ Central European University \\ e-mail: telegdya@ceu.hu
}

June 2015

ISBN $978-615-5447-93-8$

ISSN $1785377 \mathrm{X}$ 


\title{
Political Incentives and State Subsidy Allocation: Evidence from Hungarian Municipalities \\ Balázs Muraközy - Álmos Telegdy
}

\begin{abstract}
Using application-level data on successful and rejected applications for the European Union's Structural and Cohesion Funds between 2004 and 2012 in Hungary, we study which grant types are susceptible to political manipulation and how politicians achieve this goal. Using township fixed-effect estimators to attenuate the simultaneity bias between municipality characteristics and political affiliation, we find that townships with a mayor endorsed by the governing parties obtain 10 percent higher grant value per capita. This effect varies widely by grant attributes: it is of 16-19 percent when the applicant is a public entity or the project's purpose is construction so it is visible to voters and thus may bring about electoral benefits. For private applications and non-construction grants, where electoral gains are likely to be limited, the estimated effect is zero. Decomposing the township alignment effect into grant application effects (application intensity and the average value of grant) and grant decision effects (grant success rate and proportion of grant value received) reveals that both margins play a role in the political manipulation of grant distribution. When analyzing the effect of grants on votes, we show that voters indeed reward construction and public projects.
\end{abstract}

Keywords: Redistributive politics; Political alignment; European Structural Funds, Hungary

JEL classification: D72, D78, H77

\section{Acknowledgement:}

We thank Gabriella Borbás, László Halpern and Gábor Simonovits for useful comments, Szilvia Téglás for assistance in data assembly, the Global Development Network and the Hungarian Academy of Science's Lendület Program (entitled 'Firms, Strategy and Performance') for financial support. The paper benefited from presentations at the CERS-IE, Central European University, the National Bank of Hungary and Hétfa Research Institute. The views expressed in this paper are those of the authors and do not necessary reflect the official view of the National Bank of Hungary. All errors are our own. 


\title{
Politikai ösztönzők és az állami támogatások allokációja: A magyar EU-támogatások települések közötti elosztásának elemzése
}

\author{
Muraközy Balázs - Telegdy Álmos
}

\section{Összefoglaló}

Az Európai Unió Strukturális és Kohéziós alapjaiból folyósított magyarországi támogatásokat igénylő, 2004 és 2012 között nyertes és nem nyertes pályázatok adatait tartalmazó adatbázis segítségével azt vizsgáljuk, hogy milyen típusú pályázatok esetében volt a legvalószínúbb a politikai szempontokat is figyelembe vevő döntés, és milyen módon befolyásolhatták a döntéseket a politikusok. Településszintű fix hatásokat használunk a becslésben a kihagyott változók kezelésére, és azt találjuk, hogy a kormánypártok által támogatott polgármesterek által vezetett városok lakosonként körülbelül 10 százalékkal több támogatáshoz jutottak. Ez a hatás nagyban különbözik a megvalósított projektek jellemzői szerint: 16-19 százalék a lakosonkénti többlet, ha a pályázó a közszférához tartozik vagy a projektben építkezésre kerül sor, az ilyen pályázatok könnyebben megfigyelhetők a választók számára. Nulla hatást becsülünk magánszférában múködő pályázók és építkezést nem tartalmazó projektek esetében, amelyeknél a politikai haszon feltehetőleg kisebb. Ezeknek a hatásoknak a felbontása pályázási hatásra (a pályázatok száma és nagysága) és döntéshozatali hatásra (a nyertes pályázatok aránya, valamint a megnyert és pályázott összeg aránya) arra utal, hogy mindkét tényező fontos szerepet játszik a források elosztásának politikai befolyásolásában. Amikor a források késóbbi szavazatokra gyakorolt hatását vizsgáljuk, akkor kimutatható, hogy az építkezést tartalmazó és a közszférának juttatott támogatások valóban növelik a polgármesterre leadott szavazatok számát.

Tárgyszavak: redisztribúciós politika, kormánypárti és ellenzéki települések, Strukturális és Kohéziós alapok, Magyarország

JEL kódok: D72, D78, H77 


\section{INTRODUCTION}

Many countries and regions allocate substantial sums for regional subsidies in order to achieve convergence and accelerate economic growth. Among the largest of such schemes are the European Union (EU) Cohesion and Structural Funds, which spent EUR 348 billion between 2007 and 2013 to assist its less developed regions in achieving convergence, but the success of these efforts greatly depends on the efficient distribution of these funds. ${ }^{1}$ This paper aims at quantifying the effect of political manipulation of these funds in one new member state, Hungary. ${ }^{2}$ The sheer size of these transfers (amounting to 3.2 percent of Hungarian GDP between 2004 and 2012, the period we study), the fiscal constraints experienced by the government and the relatively immature political institutions make these funds especially exposed to political manipulation and, consequently, misallocation (the grants were allocated by institutions led by senior politicians). ${ }^{3}$ We use a comprehensive, application-level dataset having information on about 140,000 successful and rejected grant applications - ranging from large road construction through education of doctors to small firm-level subsidies - for this analysis.

The regional allocation of public funds has generated a great deal of attention in academic research. The literature of fiscal federalism suggests that such transfers are prone to delivering private benefits to the ruling government, as they often maximize their chances of re-election instead of social welfare (e.g., Weingast et al., 1981). More recently, theoretical papers focused on transfers between politically aligned (i.e., controlled by the same party) central and local governments (e.g., Arulampalam et al., 2009) and many papers examined this question empirically as we detail below. If extra funds generate goodwill for the incumbent politicians among voters, who cannot distinguish between the activities of governments at various levels, vote maximizing will dictate larger funds flying to politically aligned districts as otherwise the opposition can reap part of the political benefits. Previous research has also analyzed the effects of the reputation of local politicians (Golden and Picci, 2008), the severity of the political competition at the local level (Arulampalam, 2009; Case, 2001; Coats, 2006; Costa-I-Font et al., 2003; Lacrinese et al., 2006; Leigh, 2008; Levitt and

\footnotetext{
${ }^{1} \mathrm{http}$ //europa.eu/legislation_summaries/glossary/structural cohesion fund en.htm

2 The analysis, however, may also be relevant for the whole region: the 10 countries from Central and Eastern Europe accessing the EU in 2004 and 2006 are rather similar in their grade of development and institutional structure (EBRD, 2012). If these determine (at least partially) the distribution of funds, the findings of this study may apply to all of them.

3 Anecdotal evidence for such manipulation abounds. Politicians frequently state that fund transfers depend on election results. For example, János Veres, the minister of finance of the ruling left-wing coalition, made the following comment during the electoral campaign in 2006: "The next four years will bring about lots of development projects and achievements for the county...The regional distribution of funds within the country will depend on the election results" (Index Online News Website, 18.04.2006). András Tállai (secretary of state of the right-wing coalition) also stated that "...the amount of funds flying to a county...will depend in great deal on who will lead the county” (Népszava daily newspaper, 07.10.2014).
} 
Poterba, 1999), the effect of multiple upper-tier grantor governments (Solé-Ollé and Sorribas-Navarro), the variation of grant allocation across the political cycle (Veiga and Veiga, 2013) the effects of the transfers on re-election probabilities (Veiga and Veiga, 2013; Leigh, 2008; Healy and Malhotra, 2009) and the trade-off between efficiency and political factors (Cadot et al., 2006; Castells and Solé-Ollé, 2005).

Our analysis builds on this line of research but it also extends it in three directions. First, it analyzes a new EU member state, where the combination of relatively new democratic institutions and the magnitude of transfers makes such analysis especially relevant (we are not aware any papers studying this region). We also analyze the relation between political favoritism and grant characteristics: the identity of the applicant (public organization or private entity) and project visibility (which we proxy by construction and public transportation projects). 4 Finally, we examine the ways politicians achieve the partisan distribution of funds: is partisan decision-making the main source of extra funds received by aligned townships or already the volume of applications and the sums requested are biased towards favoring the governing party's municipalities?

The variation of favoritism by political alignment, project visibility and applicant type can be motivated in the following way. Each grant application is associated with some social utility on the one hand, and an expected private gain of the ruling party on the other - an increase in the chances of re-election. The utility function of politicians is a combination of the public and private gain minus the cost of reallocating funds from projects with high social value to projects with high private value. 5 If the private gain plays a role in the distribution of funds (and it is not correlated perfectly with public benefits), it will result in misallocation from the social point of view as projects with a large private benefit will crowd out some projects with high social value. In the following, we argue that such misallocation differs by the type of the project and the type of the applicant.

The private political gain may depend on the visibility of the project: even if a project is value enhancing over the long run, it may not yield electoral gains on the next election if it is only observable for few voters. Electoral gains may also depend on the identity of the applicant: if it is the local administration, rather than a private actor, politicians may more easily claim credit for it. The probability of re-election is also larger if the government places funds to districts where the local administration is politically aligned with the central government as they can easily attribute all the political value to themselves. If the opposition

\footnotetext{
4 Most studies do not distinguish between grant-types or they analyze only one type. Exceptions are Golden and Picci (2008), who distinguish between infrastructure expenditures and road/airport construction, and Healy and Malhotra (2009) between disaster relief and prevention. Our approach is closest to Leigh (2008), who distinguish between four projects comprising constructions and other, less visible activities. We know no papers studying differences by applicant type.

5 One may assume that institutions were set up in order to facilitate the efficient distribution of funds. In order to convince bureaucrats working in these institutions to favor some projects, the politicians may have to sacrifice time, political capital or even risk detection.
} 
rules the local administration, it can reap some of these benefits. As a result, this simple framework predicts that politicians will implement a number of socially less beneficial visible projects administered by public entities in aligned townships. ${ }^{6}$

An alternative hypothesis is that the ease of the execution of corruption payments affects the distribution of grants. 7 Corruption effectively materializes in grant-related procurement contracts (e.g., Goldman et al., 2013; Mironov and Zhuravskaya, 2014), and it probably can happen more easily if the contracting entities are from the same political body. This hypothesis predicts that politically aligned municipalities get more grants than those in opposition, at least if the contractor is a public entity. For private contracts, however, the political connection of the firm should matter rather than the relation between the central and local administrations. Although the construction business - which is highly correlated with the visibility of projects - is among the most corrupted industries (Hardoon and Heinrich, 2011), it is again likely that firm connections matter rather than the political alignment of the township. In our analysis, we follow the literature and hypothesize that political, rather than material gains drive the distribution of funds but corruption arguments may also play a role, especially for public applications.

We test these predictions by running regressions for different types of applications: when the applicant is a public or private entity and when the outcome of the application is visible or not (where we proxy visibility by whether the project involves construction). To do this, we aggregate up each class of project to the municipality level and use it as the dependent variable in the regression analysis.

Our comprehensive data on successful and rejected applications allow studying the ways politicians reallocate funds. We identify four margins (and use them as dependent variables in the regression analysis): the ratio of the number of applications to the population, the average amount applied for, the success rate, and the ratio of the funds allocated and applied for. The first two margins affect redistribution through the application process while the last two through the decision-making process.

Our main explanatory variable, the political alignment dummy, shows whether the governing parties endorsed the mayor on the election. The coefficient of this variable shows the advantage aligned municipalities enjoy relative to similar municipalities led by opposition mayors.

\footnotetext{
${ }^{6}$ In our data the correlation coefficient between $\log$ (public) and $\log$ (visible) grant values is 0.73. Unfortunately, our estimation strategy cannot disentangle the two effects and we treat them as two proxies for political benefits of grant distribution.

7 According to Transparency International (2014), Hungary is in the highest third of the EU in terms of corruption, with scores similar to the Czech Republic, Lithuania and Slovakia, but lower, than Romania, Bulgaria and Greece.
} 
The econometric identification of the relation between political alignment and regional fund distribution is challenged by the potential endogeneity resulting from omitted variables at the township level reflecting level of development, urbanization, remoteness, the presence of important public institutions and other important municipality characteristics. The amount of funds received by a municipality may depend on such regional variables, because richer regions may have projects that are more viable while poorer regions may have priority in regional policy. Parties with various programs may also have their voting base vary with regional development or level of urbanization. If this is the case, the estimated effect between political affiliation and the distribution of funds may be spurious. To mitigate this bias, we first control for these omitted variables by adding controls, which account for observable differences between settlements. This approach has its drawbacks, including strong functional form assumptions and unobserved heterogeneity. To alleviate this bias, we also add township fixed effects to the regression to control for factors that are fixed in time and may create spurious correlation between political leadership and the propensity to winning grants.

The empirical results show evidence for the role of political alignment in the distribution of EU funds. We find that alignment predicts an 11.4 percent higher value of grants and this effect is positive only for public and construction grants, reaching 16.4 and 19.4 percent, respectively. We estimate positive effects of the role of political alignment in both the application process and decision-making: aligned municipalities file a larger number of applications and have a higher chance of success. These effects are different from zero only for public and construction grants: political alignment induces a higher application intensity by 13 and 6 percentage points, and a higher success rate of 4 and 6 percentage points, respectively. 8 The change in application intensity of aligned municipalities suggests that the stringent regulation and scrutiny of the decision-making process places a part of political manipulation to an earlier stage of the allocation process. For example, the central government may inform the local party members how to apply or they create programs with short deadlines so uninformed parties cannot apply.

We also estimate the effect of grants on the probability of re-election of incumbent mayors, and we find positive and precisely estimated effects of 4-5 percentage points when total grants received by a township increase from the $25^{\text {th }}$ to the $75^{\text {th }}$ percentile of the distribution of all grants received by a township. More important is for the analysis that we estimate positive effects only for public and construction grants, the types identified to be distributed politically.

\footnotetext{
8 Aligned townships also apply for construction grants that are larger by 17 percent than those filed by the opposition, but this effect is statistically not significant.
} 
The structure of the paper is the following. The next section describes the political parties and the institutions of fund distribution. Section 3 discusses the data and descriptive statistics, followed by the methodology and the results while the last section concludes.

\section{INSTITUTIONS OF FUND DISTRIBUTION AND THE HUNGARIAN POLITICAL LANDSCAPE}

The purpose of the EU Structural and Cohesion Funds is to foster the convergence of poorer regions within the European Union. Although all member states contribute to these funds, they represent significant transfer of resources from richer to poorer countries. The magnitude of the funds is negotiated for seven-year planning cycles and our data include grants from the 2000-2006 and 2007-2013 cycles. At the beginning of the cycle, countries set up new programs and institutions, hence payments are relatively small in the beginning of the period and much larger near its end. Large projects involve even more preparation and time-consuming public procurement, so payments for these are quite concentrated near the end of the planning period.

EU regulations prescribe a set of institutional guarantees both regarding the distribution of funds and the control of the process (Council Regulation No. 1083/2006), and the Commission periodically monitors whether the national institutions are in line with the general rules and whether they apply the procedures appropriately. It also monitors selected individual projects. As a result, national governments have to comply with a rather large number of formal rules and procedures regarding the distribution of EU funds (Nagy and Heil, 2013). Most importantly, the funds should be allocated based on pre-determined criteria and procedures announced in the calls for different subprograms.

These criteria differ across different types of projects. Small projects have an automated process, based on whether the application satisfies the requirements of eligibility (like the size of the company). In such a case, allocation often follows a first-come first-served rule across applicants, which suit the eligibility criteria. The evaluation of large or of so-called "strategic" projects is based, however, on less transparent criteria, such as the suitability of the business plan or they have to comply with the government's sector-specific or regional strategy. Such evaluations often include many subjective elements.

The rigid institutional setting suggests that the EU forces national governments to observe some formal rules during the evaluation process itself, hence there is a limited space 
for manipulation in the decision-making process. It is important, therefore, to study the application process as well, which we do below.

\subsection{THE HUNGARIAN POLITICAL PARTY STRUCTURE AND ELECTION OUTCOMES}

Our variable of interest is the political affiliation of mayors (as we detail below). Mayors are elected with a simple voting process requiring a relative majority of votes, which contrasts with the election process of municipal council members (this being more complex and heterogeneous across different municipality types). The alternative measure - parliamentary election districts - do not perfectly overlap with townships as sometimes there are multiple election districts in large townships while multiple small municipalities may constitute a district. 9

The party structure of Hungary is such that it is quite straightforward to classify mayors as left or right wing and there was no grand coalition between the two sides. The Hungarian Socialist Party and the Alliance of Free Democrats are on the left side of the political spectrum while the Fidesz - Hungarian Civic Alliance and the Hungarian Democratic Forum on the right (the leftist and conservative parties usually governed in coalition). ${ }^{10}$ The first election studied in this paper was held in May 2006 and did not change the left-wing government coalition. The local elections (held in the same year in October), however, strengthened the opposition who won many seats in local councils and gave the mayor for a large number of townships as well. In May 2010, the government was overthrown and local elections brought a sweeping right-wing victory as well. These changes provide the variation for our fixed effects specification.

\section{DATA AND DESCRIPTIVE STATISTICS}

The host of the EU Structural and Cohesion Funds Database is the Hungarian National Development Agency. The data are available from 2004 - Hungary's accession to the EU until August 2012. The basic unit of observation is an application and the data provide information on both the successful and unsuccessful applications. To organize the application process, the Hungarian government created subprograms, which set the target activity of the EU funds. The number of subprograms is 1,621 (but in 184 there was no

\footnotetext{
9 As a robustness check, we use the political composition of the City Council to group townships by political affiliation. The procedures of the computation of this variable are available upon request.

${ }_{10}$ Two parties, which participated only in the election in 2010, the far right Jobbik (with 3 mayors) and the left wing Politics Can be Different (with 1 mayor) are coded as independent as they were not part of the government.
} 
winner application) and they cover a very large variety of activities. Examples include training programs for teachers and doctors, logistical upgrading of public services, subsidies for small and medium sized enterprises, investments to attract tourism, building and upgrading the transport infrastructure and sewerage, renovation and remodeling of schools, hospitals or towns' main squares. The following variables are available for each application: the name of the subprogram (which we use to convey information on the activity applied for), the identity of the applicant (company, public entity, nonprofit private organization, natural person), the amount of money applied for, the date of decision-making, whether the application was successful, the funds granted in case of success and the date of transfer.

The political data come from the National Election Committee, and they provide information on each election outcome at the township level. We identify each mayor's political affiliation, and code it as left or right wing. If the mayor was once associated with a party, we keep this political affiliation for the whole period even if the mayor became independent in another political cycle. We also checked the political affiliation of formally independent mayors as they can be officially endorsed by parties. To do this, we searched the internet for each independent mayor of a settlement larger than 4,ooo. When we found that the mayor was associated with a party, we coded it accordingly. These two procedures resulted in adding the political affiliation for 2,132 township-years (the first procedure being responsible for most changes). ${ }^{11}$

The municipality variables come from the T-Star Database (hosted by the Hungarian Statistical Office) which provides settlement-level indicators. We use the population and population density, the registered unemployment rate (defined as the number of registered unemployed relative to the population aged 18-59)12 and the tax revenues of the local authority (which consist mainly of company taxes and therefore correlates strongly with economic activity). The monetary variables throughout are expressed in HUF 2012, deflated by the consumer price index.

We drop the capital city from the data because its peculiar local administration system does not allow its classification along the left-right axis. ${ }^{13}$ We also exclude settlements with independent mayors (these are usually, but not exclusively, small places). As Table 1 shows, aligned townships were almost identical in numbers during in the first political cycle studied (219 and 239, respectively). The next election in 2006 reinforced the central government but the opposition won many more seats in the local election: the government had 166 mayors while the opposition 429. In the elections of 2010, the government was replaced and an

\footnotetext{
${ }^{11}$ As a robustness check, we test whether these imputations affect the results.

12 Due to lack of information at this level of disaggregation, we cannot use the standard definition of unemployment.

13 Budapest has a two-tier local administration consisting of a senior mayor for the city and mayors for each district, who can belong to different parties. Also, many projects cross the boundaries of districts.
} 
overwhelming majority of the mayors changed their political affiliation as well: the ruling party gave 607 while the opposition only 96.

The table also shows several township characteristics. In the first two political cycles, the government controlled larger and more densely populated settlements than the opposition, with higher per capita tax revenues and lower registered unemployment rates. In the last political cycle, government-led settlements were somewhat larger, less densely populated, with lower amounts of tax revenues per capita but also lower unemployment rates. The comparison of the settlements controlled by the government and opposition suggests that it is necessary to control for such settlement attributes in the regression analysis.

Figure 1 shows the total amount of subsidies distributed between 2004 and 2012, disaggregated into the fraction covered by our sample, the share of Budapest and of independent settlements, which we do not use in the analysis. The total value of funds varied widely across years, partly reflecting the EU and Hungarian political budget cycle and partly the ability of the Hungarian society to absorb grants. ${ }^{14}$ During the first 4 years of the analysis, the annual value of grants was between 220-450 billion annually (measured in HUF 2012), but during the last 5 years of the analysis it went up to HUF 1029-1768 billion. Although a large fraction of the grants went to Budapest and independent settlements had a sizable share as well, the sample used in this study covers 40-62 percent of total funds each year with the exception of 2007 when the coverage is only 22 percent. Most of the grants left out from our analysis went to Budapest; among other townships, our sample coverage is at least 59 percent each year.

We group applications by the identity of the applicant and the type of the project. An application is public if the applying organization is a public organization (typically the township's local administration, schools, hospitals etc.). We identify the type of the project based on the subprogram applied for. 'Visible' or 'construction' projects are those which involve the construction or renovation of buildings, the development, upgrading or maintenance of infrastructure (roads, railway, etc.), the renewal of public places (squares, for example) and the purchase of new vehicles in public transportation. If the subprogram does not belong to any of these activities, we call them "other." Table 2 presents the total value of grants in each political cycle along these groupings, and reveals that they were always close to even.

Figure 3 shows the average yearly value of grants per capita, received by aligned and opposition municipalities for different types of grants. To start with the total value of grants, opposition townships received about 20 percent less value per population than aligned ones.

14 Although the budget cycle can also be endogenous at the EU level (e.g., Efthyvoulou, 2012), Hungarian domestic politics could not affect it in a great deal and so we abstract from this mechanism. 
The difference by grantee and grant type also suggests that aligned municipalities were always able to collect higher grant value.

Our main outcome variable is the total value of grants given to a township in a given year, divided by its population (and we construct similar variables for public/private and construction/other grants). We always consider the time of the final decision when linking the applications to years as that seems to be the point when political influence matters the most. To analyze selection and political intervention in decision-making, we construct four additional dependent variables. We describe the application process with two variables: the number of applications per capita in the township each year and the average sum applied for. To model the decision-making process, we use the ratio of winner applications to the total number of applications, and the ratio between the sum allocated and the sum applied for.

The descriptive statistics of these variables are in Table $3 .{ }^{15}$ The average grant value per capita increased from about HUF 30 thousand in 2004-2006 to 160 thousand in 2010-2012. This is quite substantial, equivalent to about one month of net average salary, showing that these funds represented an important channel of redistribution among municipalities. The number of applications per capita was 1-2 for 1000 inhabitants. The success rate also remained more or less constant during the period at 50-60 percent. The average grant value requested increased for successful applications while rejected applications do not have a clear pattern. Finally, the ratio of grant value awarded and requested is 98 percent, showing that successful applications received all the funds they requested.

\section{EMPIRICAL METHODOLOGY}

We employ various dependent variables to test the effect of political partisanship while keeping the right hand side of the regression equation fixed. We follow the literature and set the unit of observation to be municipality-year. First we establish the relation between the total value of grants awarded to townships and our variable of interest, Aligned. This variable takes the value of 1 if the mayor of the township is affiliated with the ruling political formation, and zero otherwise. The dependent variable is the value of grants won by a township in a given year. A non-trivial share of township-years have a zero value for this variable (especially when we disaggregate the variable by grant attributes). As we prefer to log the dependent variable to interpret the estimated coefficients as proportional variation, we add 1 (HUF 1000 per capita) to the variable.

\footnotetext{
15 To save space, we present the descriptive statistics for the variables associated with the total value of grants, while the disaggregation by applicant and activity type are available upon request.
} 
The first problem encountered in the estimation of the relationship between political alignment and grant value is that townships differ from each other in aspects that may correlate with both political orientation and size of subsidies. For example, poorer municipalities may be more likely to vote for the political party promising a higher degree of redistribution while the government may indeed transfer higher amounts of subsidies to such towns, regardless of their political orientation. To control for the grade of development, we include the log of local tax revenues per capita. These come mostly from revenue-based taxes paid by enterprises and thus this variable serves as a proxy for the intensity of the local economic activity. We also include log population density in order to account for the level of urbanization. To handle differences in labor supply and labor market conditions in general, we control for the unemployment rate. We also include 8 categorical variables accounting for the type of the settlement (village, small town etc.) as well as 7 large region (NUTS-2) dummies interacted with year effects to partial out any regional and time varying shocks. The baseline equation is the following:

$$
\begin{gathered}
\log \left(\frac{\text { Grant value }_{\text {Population }}}{\text { Pot }}=\delta_{0}+\delta_{1} \text { Aligned }_{i t}+\right. \\
\delta_{2} X_{i t}+\delta_{3} \text { Region }_{i} \text { Year }_{t}+\delta_{4} \text { TownType }_{i}+\varepsilon_{i t}
\end{gathered}
$$

where $i$ denotes municipalities, $t$ denotes years and we cluster the standard errors at the municipality level. When we study how political favoritism varies by application characteristics, we replace the dependent variable by its subsets: the total value of grants at the municipality level received by private and public entities and of construction and other grants.

In this equation $\delta_{1}$ is the marginal effect of political alignment on total grant value. A positive $\delta_{1}$ suggests that aligned municipalities receive a higher level of subsidies. The measured effect, however, is an unbiased estimator of political favoritism only if alignment of the local and central governance is not correlated with settlement level unmeasured attributes, which are themselves correlated with the propensity of obtaining EU grants. Although we control for several variables, which measure the degree of urbanization and economic development, it is possible that we do not control for many township attributes enhancing or hampering municipalities from obtaining grants. To attenuate this omitted variable bias, we add township fixed effects to the regression. ${ }^{16}$

In addition to estimating the average effect of political alignment on grant value, we also identify channels through which politicians can direct funds to the aligned municipalities.

\footnotetext{
${ }^{16}$ There are 52 left-right and 6 right-left switchers around the election in 2006. In 2010 the number of switchers is 354 (these are those townships which were, and remained right-wing, so when the central government changed, they became politically aligned).
} 
We do this by disaggregating grant value per capita into four parts. Consider the following equality (aggregated at the municipality level):

$$
\frac{\text { Grant value }}{\text { Pop. }}=\frac{\text { Applic. Successful Applic. Applied Grant Value }}{\text { Pop. }} \frac{\text { Grant Value }}{\text { Applic. }} \frac{\text { Successful Applic. }}{\text { Applied Grant Value }}
$$

Total grant value per capita depends on four factors: the number of applications per capita, the ratio of successful applications, the average value of grant applied for, and the ratio between the grant value and the value applied for. ${ }^{17}$ The first and the third term describe the application process while the second and the fourth show the effects of the decision-making process on final grant value. We test the effects of these factors by using them as dependent variables in the main specification.

\section{RESULTS}

The OLS estimates are presented in the top panel of Table 4. Despite the stated goal of the European Commission that grants should decrease regional differences in development, the results in Table 4 suggest that Hungary did not meet this goal (as well as elsewhere, as Bouvet and Dall'erba (2010) find). The estimated effects of population density and unemployment rate are insignificant, while tax revenues per capita positively correlated with the value of grant per capita. This suggests that the Hungarian cohesion policy is more likely to help municipalities that are more prosperous and its role in within-country economic convergence is limited.

Column 1 of the table shows the results when the dependent variable is the total value of grants received by townships over population. The estimated coefficient of the variable Aligned represents the proportional difference in grant value per capita received by municipalities led by a mayor affiliated with the governing parties, relative to townships led by mayors of the opposition. We find only weak evidence that politically aligned townships receive larger grant value: although the effect is positive and as large as 9 log points, it is indifferent from zero in statistical terms. Columns 2 and 3 distinguish between public and private applicants (and so the dependent variable is the total value of grants received each year by public and private applicants per capita, respectively). While the coefficient of interest for private applicants is very small and statistically not significant, the effect of

\footnotetext{
17 Note that the equality is satisfied only for municipalities with at least one successful grant (or else the denominator equals zero). In the regression analysis below we will always use the maximum feasible set (for the first term the whole population, for the second the municipalities which at least one application, while for the last two the municipalities with at least one successful application). To ease interpretation, we log total grant value per capita and the average grant value requested (the other variables are proportions).
} 
Aligned is very precisely estimated for public applicants and it is as large as 0.154. This finding is in line with our first hypothesis: the government allocates larger grant value to settlements with the same political orientation if the projects are for public entities.

Columns 4 and 5 distinguish between construction projects and all other grants. The political orientation of the municipality only matters for construction projects: the effect is 16.7 percent, which is in sharp contrast with the insignificant and small coefficient associated with other projects. This finding is in line with our second hypothesis: political affiliation matters when the projects are visible.

The bottom panel of Table 4 shows the results of our preferred specification where we control for township fixed effects. The results are quite similar to the OLS estimates although here we identify the alignment effect based on switching of townships between aligned and not aligned status. In this specification, we estimate an effect on all grants of 11.4 percent (which is statistically significant at the 10-percent level). As the total value of funds was about 3 percent of the GDP (as we documented above), the grant value altered to aligned municipalities was 0.34 percent of the GDP each year, a rather sizable reallocation of wealth in the economy. Public grants are associated with an effect of 16.4 percent and construction grants with an effect 19.4 percent. The alignment effect of private and non-visible grants is zero, suggesting the politicians engage in clientelism only if the grants are likely to bring political benefits.

The insignificant estimated effects associated with those grants that are unlikely to bring short-term political benefits provides indirect evidence of the reliability of our identification strategy: if the results were driven by the divergent grades of development of aligned and not aligned townships, there are no reasons to expect differences between private and public grant values. We would rather expect larger value for private grants as they are more likely to depend on the local opportunities for investment, such as the number of firms or innovative ideas of managers.

How do our results compare to other studies? Solé-Ollé and Sorribas-Navarro (2008) estimate the political alignment effect to be of EUR 7-11 per capita in Spain. In our data, the average value of public grants per capita is HUF 34 thousand. Multiplying this with the estimated coefficient of 0.157 , it results that the value difference of political clientelism for public projects is HUF 5600 (EUR 18.5) per capita. In the case of visible projects, the extra value received by the citizens of politically aligned townships is HUF 4700 each year (EUR 16). The total extra grant value was HUF 7500 (EUR 25). These results are about 1.5-2 times larger than those from Spain and even by much more if compared to the proportional difference in the average salary in the two countries, which was about 2.8 (Eurostat Earnings Data). Arulampalam et al. (2009) find that in India a state that is aligned and swing, obtain 16 percent higher transfers. This is larger than our finding for the total value of grants but 
very similar to what we estimate for public and construction projects. Leigh (2008) analyzes four programs, one being the construction of roads while the others resulting in less visible outcomes. He finds the strongest partisan allocation for road construction. For the other three programs he estimates significant effects for only one, and the coefficients are much smaller than for road construction (the magnitudes are not comparable to our results as his dependent variable is value of grant per electoral seat).

\subsection{ROBUSTNESS OF THE RESULTS}

We start the robustness checks with testing whether our imputations of the mayor's political affiliation affects the main results. We use as the variable of interest the uncleaned variable (so we do not correct it with information from the internet and do not impute the political affiliation of independent mayors if they once were affiliated with a party). The results, presented in the first row of Table 5 , suggest that these imputations are innocuous and do not change the results.

In the next robustness check, we use the composition of the city council as an alternative measure of alignment. ${ }^{18}$ The results are qualitatively similar, but larger in magnitude than in our preferred specification. In this specification, the effect of political alignment on public grants is 0.29 and on visible grants 0.35 , twice as large as in the basic specification.

We also run random effects Tobit regressions to account for the censoring of the dependent variable (i.e., the municipality-years with zero grants). The results are also robust to this change in the regression method.

The analysis above may be criticized on the grounds of not taking into account the decision-making method. Some - typically smaller subprograms - are allocated with automatic methods while larger subprograms are more discretionary. We can distinguish between subprograms with automated and more discretionary decision-making process. As expected, when running our regressions for these two groups, we find significant positive political effects only for the discretionary grants, and nothing for the automated ones. These variables, however, are strongly correlated with our variables of interest: for example, almost all the construction projects are discretionary. To check whether this feature of the decisionmaking process drives our results, we use grants only from discretionary subprograms. As the last row of Table 5 presents, the results are very similar to the main results.

\footnotetext{
${ }^{18}$ Note that we have a smaller sample here because in a number of smaller municipalities the mayor has a party alignment while candidates for the city council are independent. The correlation between the two variables is 0.65 for municipalities with a non-independent city council and mayor.
} 
Another potential source of bias is the quality and experience of local politicians, which may vary by political alignment. If aligned mayors tend to be more senior and more influential than those in opposition, our results may be biased. To rule this out, we augment the regression with a variable measuring the tenure of the mayor (the longer the person served as a mayor, the more likely he/she has good connections). The second variable measuring the mayor's influence is a dummy variable that equals 1 if the mayor is a member of parliament. Finally, we add variables measuring the proportion of votes cast for the incumbent mayor to proxy the underlying quality of the politicians. The results are in Appendix Table A1 and show that these variables are not correlated with grant values won by the township except for tenure, which has a negative effect. The estimated effect of Aligned, however, does not change after the inclusion of these variables in the regression.

\section{$5 \cdot 3$}

EFFECTS OF ALIGNMENT ON APPLICATIONS AND DECISION MAKING

Having established the effect of political alignment on grant value, we turn our attention to the channels used to transfer larger grants to politically aligned townships. We run the same fixed-effects regressions as before, but with dependent variables taken from the decomposition presented in the methodology section. The first line of Table 6 shows the results when the dependent variable is the number of applications per capita at the municipal level. Politically aligned municipalities file 11 percent more applications relative to population size than townships in opposition. We find statistically significant differences for the two politically important applications types: public and constructions (with estimated coefficients of 0.13 and 0.06 , respectively).

The second margin studied is the success rate of applications (defined as the ratio between the number of successful applications and all applications). The analysis reveals economically meaningful and statistically significant differences again for public and construction applications of 4 and 6 percent, respectively. This result may also interpreted as visibility being important for politicians: a larger number of grants results in larger number of voters benefitting and thus more support for the government (Leigh, 2008).

The next margin is the average value of grant requested by successful applications and the analysis uncovers important differences for construction applications. Although the coefficient is not statistically significant, it is as large as 17 percent. ${ }^{19}$ Finally, we find no alignment effect on the ratio of the value of grant awarded and value requested.

19 The p-value associated with the coefficient is 0.13 . When we use the alignment of the city council as the variable of interest, the effect is similar in magnitude but it becomes statistically significant. 
The large - albeit insignificant - effect of alignment on grant value can have two interpretations: aligned townships apply for larger grants or the government selects the large grants if the township is aligned. The estimated effects of Aligned for the sample of unsuccessful applications (presented in Appendix Table A2) are very similar to those obtained on successful applications, supporting the hypothesis that aligned townships generally file larger grants and it is not the government what selects the large aligned grants during the decision making process.

Our results therefore suggest that while the government favors its own districts in the decision-making process, it is at least as important for the distribution of grants that applications are very different between aligned and opposition townships: both the application intensity and the value of applications are larger for the earlier. Anecdotal evidence suggests two mechanisms that affect the application process. First, the government can make calls for applications with specific requirements and tight deadlines, so informed townships can easily apply and eventually win. Second, it seems to be common knowledge that local administrations that are in opposition can win only small amounts of money and thus they apply for smaller grants.

Another mechanism that can foster the partisan distribution of grants is the manipulation of co-payments, which may be substantial: in our sample, the average value of co-payments is $33 \%$ of the total cost of the project. If aligned municipalities are allowed to have smaller share of co-payment, or the government helps them to obtain the necessary funds, they can also apply for larger grant value. To test whether the share of co-payment in the total cost of projects varies by political alignment, we run our regression with the dependent variable being the total value of co-payments divided by the total value of grants received. We find very small effects which are statistically significant only for private and public grants with magnitudes (standard errors) of 0.015 (0.007) and -0.017 (0.004). These results, therefore, do not support the hypothesis that the government manipulates the share of co-payments, at least not to a large extent.

\section{THE EFFECT OF GRANT DISTRIBUTION ON VOTING OUTCOMES}

Having established the effect of political partisanship on the distribution of funds, in this section we analyze whether funds indeed have an effect on election outcomes. We focus on incumbent mayors' and our estimation equation is the following:

$$
\begin{gathered}
\Delta \text { Vote }_{i t}=\alpha_{0}+\alpha_{1} \log \left(\frac{\text { Grant value }_{\text {Population }}}{\text { Pot }}+\alpha_{2} \text { Vote }_{i t-4}+\right. \\
\alpha_{3} \text { Party }_{i t} \text { Year }_{t}+\Delta X_{i t}+u_{i t s}
\end{gathered}
$$


where $i$ indexes townships and $t$ indexes political cycles. The dependent variable is the change in the share of votes cast for the mayor between the current and preceding election (we differentiate the dependent variable to get rid of time-invariant mayor effects). Vote Vit-4 $_{\text {it }}$ equals the votes for the mayor in the preceding election, which is included to control for additional unobserved heterogeneity and regression to the mean. Our variable of interest is Grant value/Population, the total value of EU grants paid to municipality $i$ during the political cycle (in contrast to our main regressions, here we consider the sums paid rather than awarded, assuming that voters can only observe ongoing projects, but using the sum awarded does not change the results qualitatively). $\Delta X_{i t}$ includes the same controls as in our main specification. Finally, we control for party affiliation and year interactions. Note that we only include municipalities where the mayor elected in $t-4$ also participated in the election in year $t .^{20}$

The results, presented in Table 7, are in line with the hypothesis that local politicians can benefit from public and construction grants. The first column shows the effect of total grants on mayoral votes: doubling EU grants yields a 0.7 percentage point increase in the votes for the incumbent major. The effect is 1.2 percentage points for public and visible grants while we measure no effect for the other two types. ${ }^{21}$

How large is this effect? Multiplying the alignment effect on total grant value (estimated to be of 0.114) with the coefficient of 0.007 , results that the aligned incumbent mayor receiving the average value of extra grants received only 0.08 percentage points more votes than its competitor. It is likely, however, that the partisan distribution of grants, especially in constructions, is lumpy: some townships get a lot while others get nothing. At the $75^{\text {th }}$ percentile, the log grant value is 5.18, which results in an increase of the votes by 3.6 percentage points. In the case of public grants, the effect at the $75^{\text {th }}$ percentile is over 5 percentage points and for construction grants it is 4 percentage points, which is large enough to turn around an election. ${ }^{22}$ This suggests that the distribution of EU funds provides an important opportunity for politicians to influence close elections that may lead to serious inefficiencies in the allocation of these funds.

\footnotetext{
${ }^{20}$ As well as before, we drop townships with independent mayors, though the results are very similar if they are included in the analysis.

${ }^{21}$ One possible concern with this strategy is that grants can also serve as a proxy for the performance of the mayor in the given electoral cycle (even though we first difference the equation). While this is possible, the heterogeneous effect of different types of grants suggests that we are - at least partially - measuring the effect of the grants on votes cast on the mayor.

22 Veiga and Veiga (2013) find that a one standard deviation increase in the growth of grant value per capita increase the vote share by almost half percentage points. Leigh estimates that the same one standard deviation increase boosts votes by 2.4 percentage points. Finally, Healy and Malhotra (2009) estimate the effect of disaster relief spending on election results and find that increasing it from USD 1 per capita to USD 10 results in an increase of votes for the incumbent party by 0.77 percentage points.
} 


\section{CONCLUSIONS}

This paper analyzed the partisan distribution of the EU Structural and Cohesion Funds in a new EU member state, Hungary. Using universal application-level data for the first 9 years of EU accession of Hungary and controlling for township fixed effects to account for the heterogeneity of townships characteristics, we find that politically aligned municipalities receive 11.4 percent larger grant value than those that are ruled by the opposition. This effect varies widely by application type: we measure 16-19 percent higher grant value per capita in the case of those grants where the applicant was a public entity or the outcome of the grant involved construction, renovation, infrastructure or public transportation, while for private and less visible projects we do not find such effects.

We also look at channels of political favoritism, and find that not only decision making is biased in favor of aligned townships, but also the application process: the success rate is larger by 6 percentage points while the application intensity by $6-13$ percentage points. We find significant effects only for public and construction grants. The analysis suggests, therefore, that under the scrutiny of the European Commission, politicians manipulate the decision-making process to a relatively small extent; rather, they assist aligned applicants to submit a larger number of applications and ask for more money.

Finally, we look at the effect of grants on the electoral gains of city mayors, and we find that the large inflow of public and construction moneys may increase the chances of reelection by 4-5 percentage points, which may be enough to turn around an election.

These findings have important policy implications. If visible and public grants are more vulnerable to political partisanship, they should perhaps receive special treatment in the EU regulation. More important is that the stringent regulation concerning the decision-making process and the scrutiny of spending does not seem to be very effective in the light of our results. In order to mitigate political favoritism and its likely negative effects on income inequality and the effectiveness of EU grants, the regulation may also require more transparency in this early part of the process with, for example, restricting the possibility of personalized calls and very short application deadlines. 


\section{References}

Arulampalam, Wiji, Sugato Dasgupta, Amrita Dhillon, Bhaskar Dutta (2009), "Electoral Goals and Center-State Transfers: A Theoretical Model and Empirical Evidence from India." Journal of Development Economics 88, 103-119.

Bouvet, Florence, and Sandy Dall'erba (2010), "European Regional Structural Funds: How Large is the Influence of Politics on the Allocation Process?" Journal of Common Market Studies 48(3), 501-528.

Cadot, Olivier, Lars-Hendrik Röller, Andreas Stephan (2006), "Contribution to Productivity of Pork Barrel? The Two Faces of Infrastructure Investment.” Journal of Public Economics 90, 1133-1153.

Case, Anne (2001), "Election Goals and Income Redistribution: Recent Evidence from Albania." European Economic Review 45, 405-423.

Castells, Antoni, Albert Solé-Ollé (2005), "The Regional Allocation of Infrastructure Investment: The Role of Equity, Efficiency and Political Factors.” European Economic Review 49, 1165-1205.

Coats, Morris R., Gokhan Karahan, Robert D. Tollison (2006), "Terrorism and PorkBarrel Spending.” Public Choice 128, 275-287.

Costa-I-Font, Joan, Eduardo Rodrigues-Oreggia, Dario Lunapla (2003), "Political Competition and Pork-Barrel Politics in the Allocation of Public Investment in Mexico." Public Choice 116, 185-204.

Efthyvoulou, Georgios (2012), „Political Budget Cycles in the European Union and the Impact of Political Pressures." Public Choice 153, 295-327.

European Bank for Reconstruction and Development (EBRD) (2012), Transition Report, 2012. England: EBRD.

Eurostat Earnings Data website,

http://ec.europa.eu/eurostat/tgm/table.do?tab=table\&init=1\&language=en\&pcode=tpso 0175\&plugin $=1$.

Eurostat National

Accounts, epp.eurostat.ec.europa.eu/portal/page/portal/national_accounts/data.

Golden, Miriam A., Lucio Picci (2008), "Pork-Barrel Politics in Postwar Italy, 1953-94." American Journal of Political Science 52(2), 268-289.

Goldman, Eitan, Jörg Rocholl, Jongil So (2013), "Politically Connected Boards of Directors and the Allocation of Procurement Contracts." Review of Finance 13(5), 1617-1648.

Hardoon, Deborah, Finn Heinrich (2011), “Bribe Payers Index 2011." Transparency International.

Healy and Malhotra (2009), "Myopic Voters and Natural Disaster Policy." American Political Science Review 103(3), 387-406.

Lacrinese, Valentino, Leonzio Rizzo, Cecilia Testa (2006): Allocating the US Federal Budget to the States: the Impact of the President, Journal of Politics, Vol. 68, Issue 2, pp. 447-456.

Leigh, Andrew (2008), "Bringing Home the Bacon: An Empirical Analysis of the Extent and Effects of Pork-Barreling in Australian Politics.” Public Choice 137, 279-299.

Levitt, Steven D. and James M. Poterba (1999): Congressional distributive politics and state economic performance, Public Choice 99, 185-216. 
Mironov, Maxim, Ekaterina Zhuravskaya (2014), "Corruption in Procurement and the Political Cycle in Tunneling: Evidence from Financial Transactions Data.” Mimeo.

Nagy, Sándor Gyula, Péter Heil (eds.) (2013), “A kohéziós politika elmélete és gyakorlata: Európai uniós fejlesztési programok - belülről nézve" (Cohesion politics in theory and practice: European Union's development projects - an insider's view), Budapest: Akadémiai Kiadó.

Solé-Ollé, Albert, Pilar Sorribas-Navarro (2008), "The Effects of Partisan Alignment on the Allocation of Intergovernmental Transfers. Difference-in-Differences Estimates for Spain.” Journal of Public Economics 92, 2302-2319.

Transparency International Website (2014), http://www.transparency.org/cpi2014.

Veiga, Linda Goncalves, Francisco José Veiga (2013), "Intergovernmental Fiscal Transfers as Pork Barrel.” Public Choice 155, 335-353.

Weingast, Barry R., Kenneth A. Shepsle, Christopher Johnsen (1981): The Political Economy of Benefits and Costs: A Neoclassical Approach to Distributive Politics, $\begin{array}{lllll}\text { Journal of } & \text { Political 640momy } & \text { 642-664. }\end{array}$ 
Table 1

\section{Municipality Characteristics by Political Orientation}

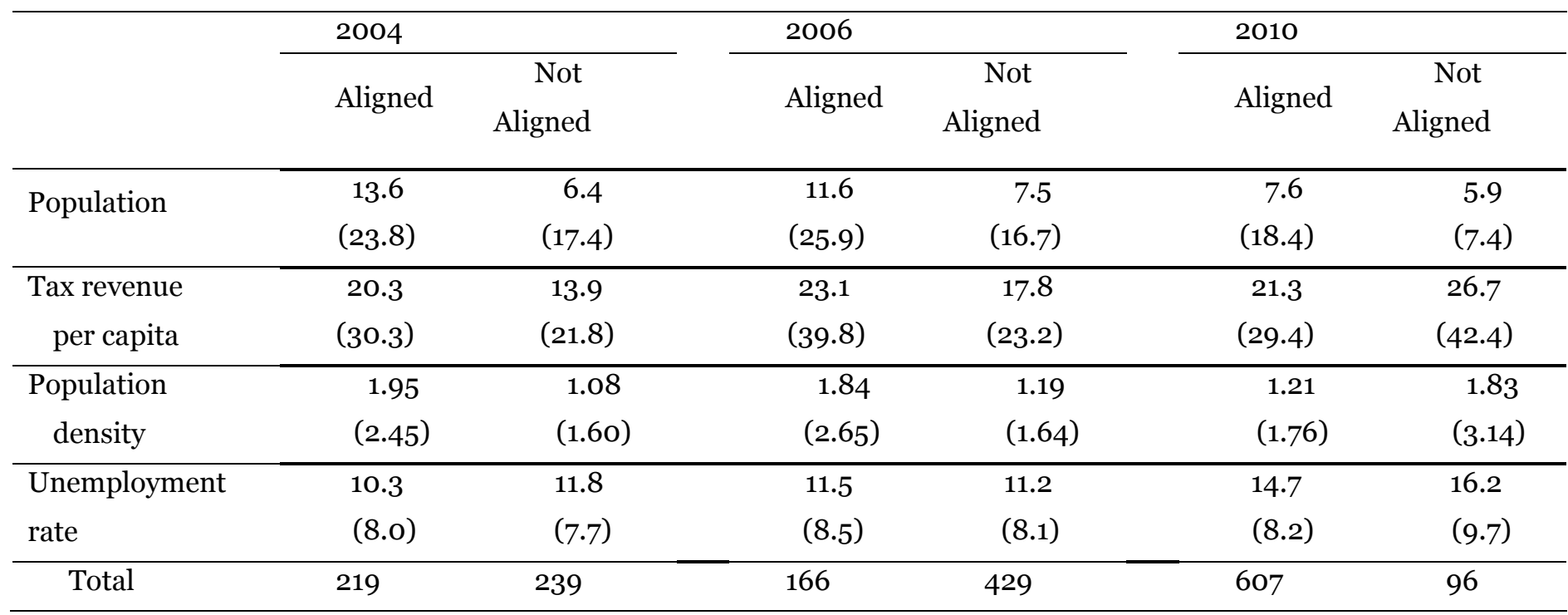

Notes: Population measured in thousands, tax revenues measured in thousands of 2012 HUF, density of population measured by the number of population per hectare. Unemployment rate measured by the number of registered unemployed over the population 18-59. 
The Distribution of Grant Value by Year

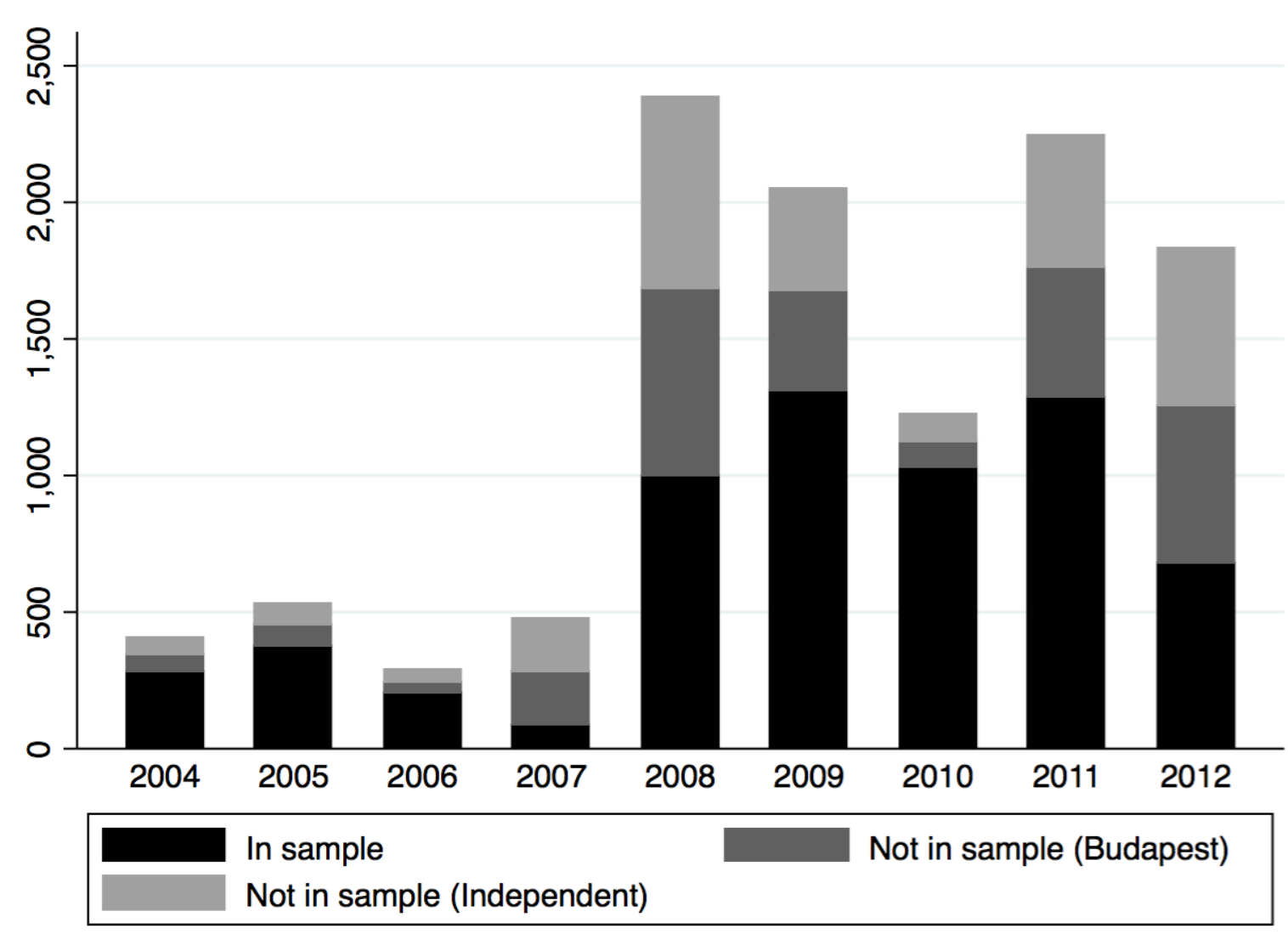

Notes: the bars represent the total value of grants distributed each year in HUF 2012. 
Table 2

Distribution of Grant Value by Applicant Type and Visibility

\begin{tabular}{lllll}
\hline & \multicolumn{2}{c}{ Applicant Type } & \multicolumn{2}{c}{ Type of Activity } \\
\cline { 2 - 5 } & Public & Private & Construct & Other \\
\hline $2004-2006$ & 0.42 & 0.58 & 0.55 & 0.45 \\
$2006-2010$ & 0.50 & 0.50 & 0.46 & 0.54 \\
$2010-2012$ & 0.53 & 0.47 & 0.52 & 0.48 \\
\hline $2004-2012$ & 0.50 & 0.50 & 0.49 & 0.51 \\
\hline
\end{tabular}

Notes: $\mathrm{N}=7007$ municipality-years. Private $=$ applicant private; Public $=$ applicant public organization; Construction = grants in construction and renovation of buildings, infrastructure, public transportation vehicles; Other $=$ grants not in the construction category. 
Figure 2

\section{Yearly Grant Value by Political Alignment}

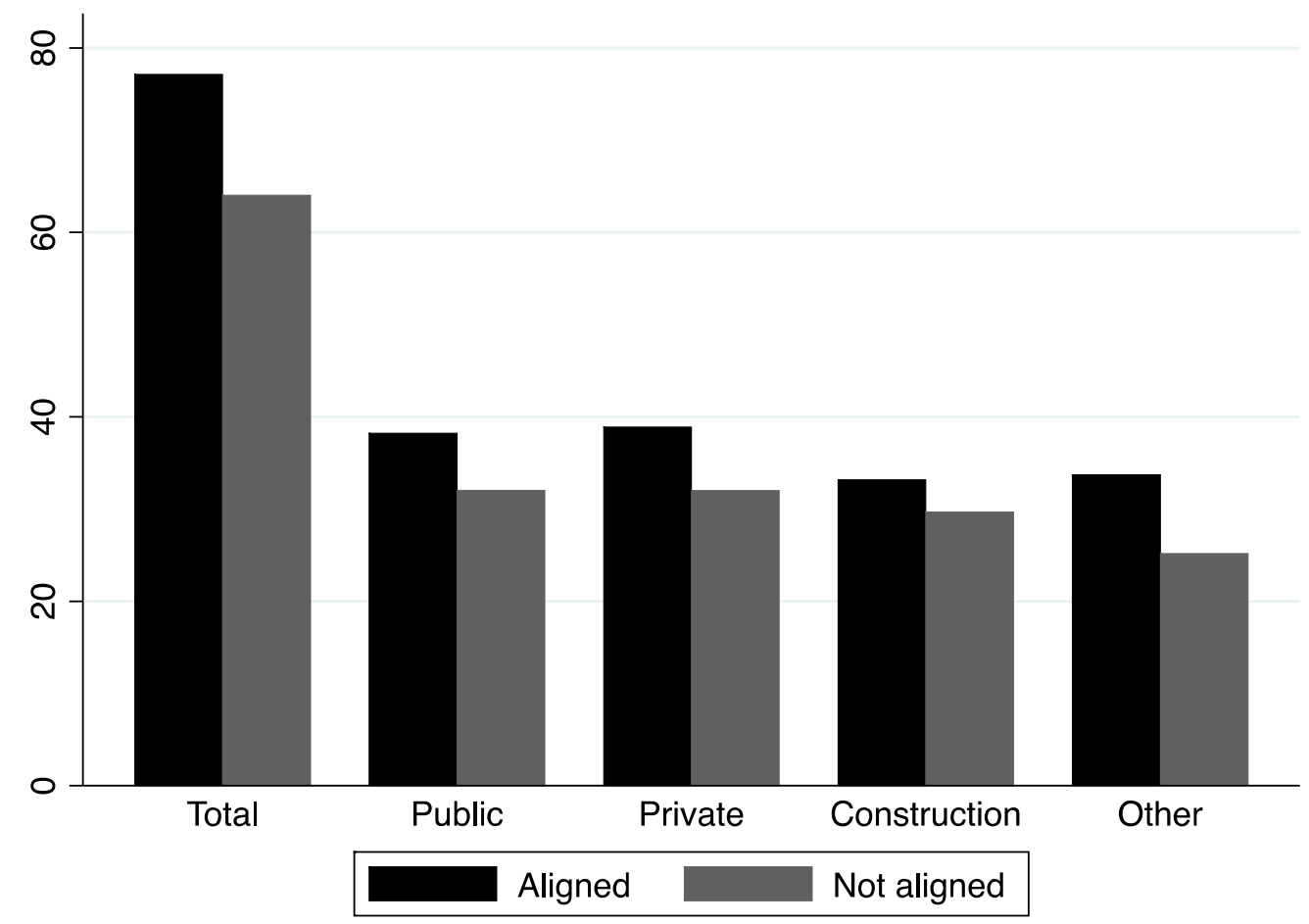

Note: $\mathrm{N}=7007$ township-years. The size of the bars represent the total value of grants. 
Table 3

\section{Dependent Variables by Political Cycle}

\begin{tabular}{lccc}
\hline & $2004-2006$ & $2006-2010$ & $2010-2012$ \\
\hline Grant Value per Capita & 0.030 & 0.059 & 0.161 \\
Applications/Population & $(0.059)$ & $(0.144)$ & $(1.426)$ \\
Successful Application/Application & 0.001 & 0.001 & 0.002 \\
Grant Value Requested/Successful Application & $(0.001)$ & $(0.001)$ & $(0.002)$ \\
& 0.509 & 0.590 & 0.542 \\
Grant Value Awarded/Grant Value Requested & $(0.233)$ & $(0.266)$ & $(0.300)$ \\
& 65.0 & 95.8 & 215.2 \\
Grant Value Requested/Rejected Application & $(146.6)$ & $(399.7)$ & $(1572.4)$ \\
& 0.984 & 0.979 & 0.985 \\
& $(0.040)$ & $(0.059)$ & $(0.066)$ \\
& 80.1 & 102.0 & 74.8 \\
\hline
\end{tabular}

Notes: $\mathrm{N}=7007$ township-years. Grant value measured in Millions of HUF 2012.

Grant value awarded/grant value requested is measured for successful applications. 
Table 4

The Effect of Political Orientation on Grant Value per Capita

\begin{tabular}{lccccc}
\hline & & \multicolumn{2}{c}{ Applicant Type } & \multicolumn{2}{c}{ Activity Type } \\
\cline { 3 - 6 } & Total & Public & Private & Construction & Other \\
\hline CROSS SECTION (OLS) & & & & & \\
Aligned & 0.092 & $0.154^{* * *}$ & -0.022 & $0.167^{* * *}$ & -0.003 \\
& $(0.058)$ & $(0.055)$ & $(0.046)$ & $(0.047)$ & $(0.050)$ \\
Tax revenue per capita & $0.118^{* * *}$ & 0.009 & $0.162^{* * *}$ & -0.024 & $0.183^{* * *}$ \\
& $(0.041)$ & $(0.034)$ & $(0.033)$ & $(0.026)$ & $(0.031)$ \\
Population density & 0.047 & 0.033 & 0.041 & 0.044 & 0.032 \\
& $(0.055)$ & $(0.046)$ & $(0.045)$ & $(0.034)$ & $(0.046)$ \\
Unemployment rate & -0.003 & 0.000 & -0.004 & -0.000 & -0.001 \\
& $(0.006)$ & $(0.004)$ & $(0.005)$ & $(0.004)$ & $(0.004)$ \\
\hline $\mathrm{R}^{2}$ & 0.348 & 0.273 & 0.345 & 0.207 & 0.364 \\
\hline PANEL (FIXED EFFECTS) & & & & $0.194^{* * *}$ & -0.018 \\
Aligned & $0.114^{*}$ & $0.164^{* * *}$ & -0.038 & $(0.058)$ & $(0.053)$ \\
\hline $\mathrm{R}^{2}$ (within) & $(0.060)$ & $(0.061)$ & $(0.050)$ & 0.132 & 0.168 \\
\hline
\end{tabular}

Notes: $\mathrm{N}=7007$. Dependent variable: $\log$ (yearly total grant value/population). For o grant value the dependent variable replaced with o. The regressions control for region-year ( 7 regional categories) and type of settlement ( 7 categories). The panel regression also includes the variables presented for the OLS regression. In election years multiple time periods are used and they are weighted such that the sum of weights equal 1. Standard errors (clustered at the regional level) in parentheses. ${ }^{* * *}=$ significant at the $1-^{*}$ percent level; ${ }^{* *}=$ significant at the 5 -percent level; ${ }^{*}=$ significant at the 10 -percent level. 
Table 5

The Effect of Political Orientation on Grant Value per Capita

(Alternative Specifications)

\begin{tabular}{|c|c|c|c|c|c|}
\hline & \multirow[b]{2}{*}{ Total } & \multicolumn{2}{|c|}{ Applicant Type } & \multicolumn{2}{|c|}{ Activity Type } \\
\hline & & Public & Private & Construction & Other \\
\hline \multicolumn{6}{|c|}{ Uncleaned Mayor Variable } \\
\hline Aligned & $\begin{array}{c}0.097 \\
(0.080)\end{array}$ & $\begin{array}{c}0.179^{* *} \\
(0.085)\end{array}$ & $\begin{array}{l}-0.041 \\
(0.061)\end{array}$ & $\begin{array}{l}0.194^{* *} \\
(0.080)\end{array}$ & $\begin{array}{c}0.015 \\
(0.069) \\
\end{array}$ \\
\hline $\mathrm{R}^{2}$ & 0.215 & 0.202 & 0.151 & 0.161 & 0.203 \\
\hline \multicolumn{6}{|c|}{ Political Alignment of City Council } \\
\hline Aligned & $\begin{array}{l}0.233^{* * * *} \\
(0.084)\end{array}$ & $\begin{array}{l}0.286^{* * * *} \\
(0.106)\end{array}$ & $\begin{array}{c}0.063 \\
(0.081) \\
\end{array}$ & $\begin{array}{l}0.346^{* * *} \\
(0.105) \\
\end{array}$ & $\begin{array}{c}0.045 \\
(0.086) \\
\end{array}$ \\
\hline $\mathrm{R}^{2}$ & 0.310 & 0.293 & 0.239 & 0.221 & 0.321 \\
\hline \multicolumn{6}{|c|}{ Tobit regression } \\
\hline Aligned & $\begin{array}{c}0.065 \\
(0.047) \\
\end{array}$ & $\begin{array}{l}0.151^{* * * *} \\
(0.042)\end{array}$ & $\begin{array}{l}-0.052 \\
(0.036) \\
\end{array}$ & $\begin{array}{l}0.157^{* * *} \\
(0.039)\end{array}$ & $\begin{array}{c}0.001 \\
(0.037) \\
\end{array}$ \\
\hline Log Likelihood & -11387 & -9136 & -9023 & -5427 & -9299 \\
\hline \multicolumn{6}{|c|}{ Discretionary Subprograms } \\
\hline Aligned & $\begin{array}{c}0.128^{* *} \\
(0.062)\end{array}$ & $\begin{array}{l}0.177^{* * *} \\
(0.063)\end{array}$ & $\begin{array}{l}-0.033 \\
(0.051) \\
\end{array}$ & $\begin{array}{l}0.194^{* * * *} \\
(0.058)\end{array}$ & $\begin{array}{c}0.001 \\
(0.054) \\
\end{array}$ \\
\hline $\mathrm{R}^{2}$ & 0.160 & 0.150 & 0.123 & 0.132 & 0.163 \\
\hline
\end{tabular}

Notes: $\mathrm{N}=4867$ in the first panel, 3192 in the second, 7007 in the third and fourth. Dependent variable: $\log (y e a r l y ~ g r a n t$ value/population). For o grant value the dependent variable replaced with 0 . The regressions control for $\log (\operatorname{tax}$ revenue/population), $\log$ (population density) the unemployment rate, region-year (7 regional categories), and type of settlement (7 categories). Municipality fixed-effects removed. In election years multiple time periods are used and they are weighted such that the sum of weights equal 1. In the tobit regressions the numbers represent marginal effects. Standard errors (clustered at the regional level) in parentheses. ${ }^{* *}=$ significant at the 1 -percent level; ${ }^{* *}=$ significant at the 5 -percent level. 
Table 6

The Effect of Political Influence on Application Process and Grant Success

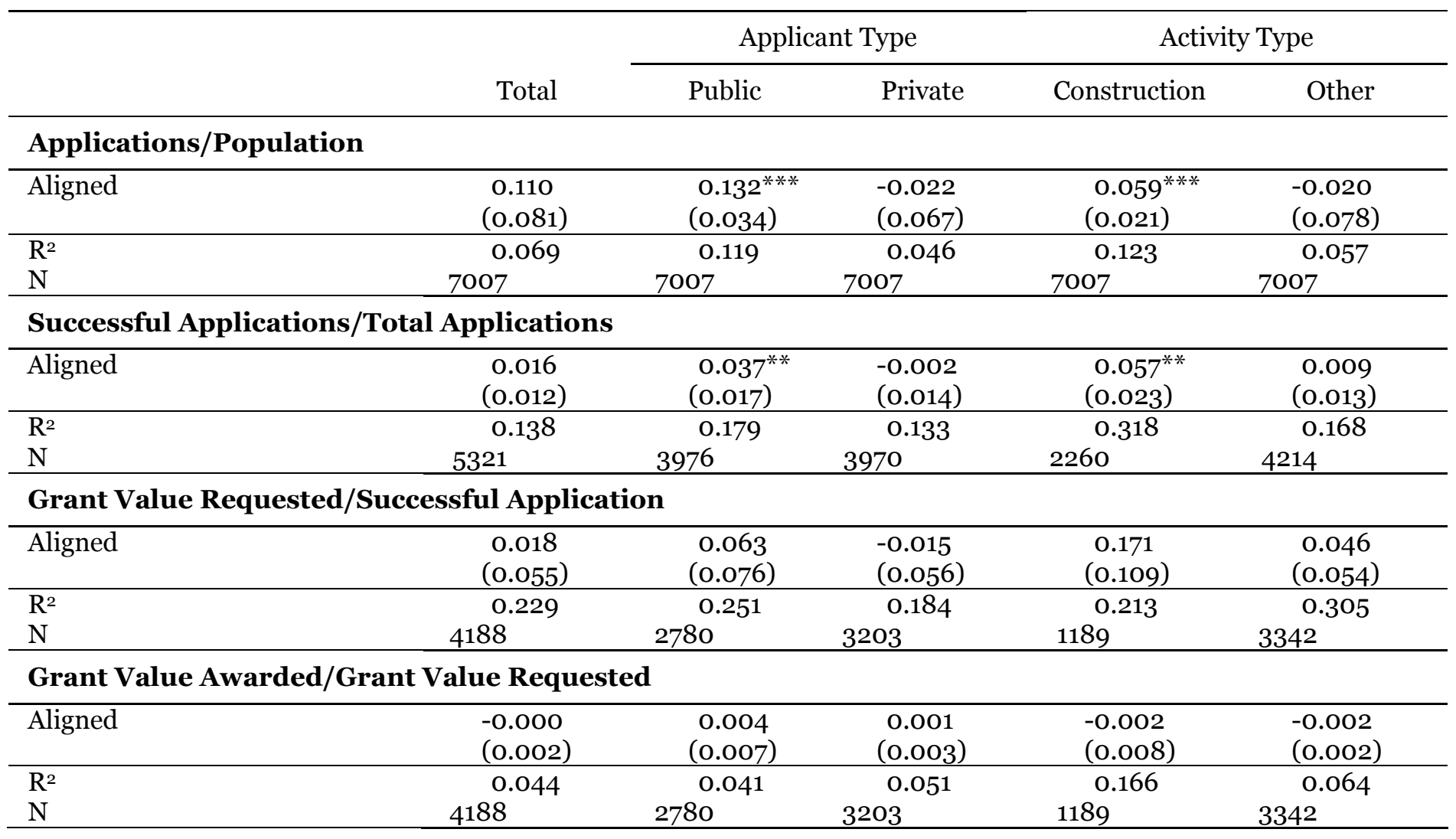

Note: The regressions control for $\log$ (tax revenue/population), $\log$ (population density), unemployment rate, region-year (7 regional categories) and type of settlement (7 categories). Municipality fixed-effects removed. In election years multiple time periods are used and they are weighted such that the sum of weights equal 1. Standard errors (clustered at the regional level) in parentheses. ${ }^{* * *}=$ significant at the 1 -percent level; ${ }^{* *}=$ significant at the 5 -percent level. 
The Effect of Grants on Election Outcomes

\begin{tabular}{|c|c|c|c|c|c|}
\hline (1) & \multicolumn{2}{|c|}{ (2) } & \multicolumn{3}{|c|}{ (3) } \\
\hline \multirow[t]{4}{*}{ Total } & $0.007^{* *}$ & Public & $0.012^{* * *}$ & Construction & $0.012^{* * *}$ \\
\hline & (0.002) & & (0.002) & & (0.002) \\
\hline & & Private & -0.000 & Other & 0.000 \\
\hline & & & (0.002) & & (0.002) \\
\hline $\mathrm{R}^{2}$ & 0.244 & & 0.249 & & 0.249 \\
\hline
\end{tabular}

Notes: $\mathrm{N}=4746$. Dependent variable: change in votes for the incumbent mayor. The regression controls for $\log$ (tax revenue/population), $\log$ (population density), unemployment rate, interactions between time effects and the party affiliation of the mayor and mayors' share of votes in the preceding election. Standard errors (clustered at the regional level) in parentheses. ${ }^{* * *}=$ significant at the 1-percent level. 


\section{Appendix}

Table A1

Effect of Mayor Attributes on Grant Distribution

\begin{tabular}{lccccc}
\hline & & \multicolumn{2}{c}{ Applicant Type } & \multicolumn{2}{c}{ Activity Type } \\
\cline { 3 - 6 } & Total & Public & Private & Construction & Other \\
\hline Aligned & $0.126^{* *}$ & $0.195^{* * *}$ & -0.038 & $0.200^{* * *}$ & -0.002 \\
& $(0.060)$ & $(0.061)$ & $(0.050)$ & $(0.057)$ & $(0.053)$ \\
Tenure & $-0.017^{* *}$ & $-0.029^{* * *}$ & $-0.014^{*}$ & -0.012 & $-0.022^{* * *}$ \\
& $(0.008)$ & $(0.008)$ & $(0.007)$ & $(0.008)$ & $(0.008)$ \\
Member of parliament & 0.037 & -0.081 & 0.161 & 0.061 & 0.024 \\
& $(0.116)$ & $(0.120)$ & $(0.107)$ & $(0.135)$ & $(0.124)$ \\
Votes between 50-70\% & -0.030 & -0.019 & -0.015 & -0.013 & -0.025 \\
& $(0.085)$ & $(0.088)$ & $(0.074)$ & $(0.085)$ & $(0.077)$ \\
Votes between 70-90\% & -0.095 & 0.012 & $-0.176^{*}$ & -0.016 & -0.125 \\
& $(0.108)$ & $(0.112)$ & $(0.094)$ & $(0.107)$ & $(0.098)$ \\
Votes > 90\% & 0.023 & 0.087 & -0.097 & 0.050 & -0.089 \\
& $(0.089)$ & $(0.095)$ & $(0.077)$ & $(0.091)$ & $(0.084)$ \\
\hline $\mathrm{R}^{2}$ & 0.178 & 0.174 & 0.119 & 0.133 & 0.170 \\
\hline
\end{tabular}

Notes: $N=7007$. Dependent variable: $\log$ (grant value/population). The regressions control for $\log ($ tax revenue/population), $\log$ (population density), unemployment rate, region-year (7 regional categories) and type of settlement (7 categories). Municipality fixed-effects removed. In election years multiple time periods are used and they are weighted such that the sum of weights equal 1. Standard errors (clustered at the regional level) in parentheses. ${ }^{* * *}=$ significant at the 1 -percent level; ${ }^{* *}=$ significant at the $5^{-}$ percent level; * = significant at the 10-percent level. 
Table A2

\section{The Effect of Political Influence on Average Grant Value per Capita (Rejected Applications)}

\begin{tabular}{lccccc}
\hline & & \multicolumn{2}{c}{ Applicant Type } & \multicolumn{2}{c}{ Activity Type } \\
\cline { 3 - 6 } & Total & Public & Private & Construction & Other \\
\hline \multicolumn{2}{l}{ Grant Value Requested/Rejected Application } & & & 0.060 \\
\hline Aligned & 0.054 & 0.090 & 0.045 & 0.187 & $(0.058)$ \\
\hline $\mathrm{R}^{2}$ & $(0.057)$ & $(0.069)$ & $(0.064)$ & $(0.118)$ & 0.267 \\
$\mathrm{~N}$ & 0.204 & 0.255 & 0.188 & 0.245 & 2926 \\
\hline
\end{tabular}

Note: The regression controls for $\log ($ tax revenue/population), $\log$ (population density), unemployment rate, region-year (7 regional categories) and type of settlement (7 categories). Municipality fixed-effects removed. In election years multiple time periods are used and they are weighted such that the sum of weights equal 1. Standard errors (clustered at the regional level) in parentheses. 